\title{
SIFAT PANGGILAN ALLAH: STUDI TERHADAP PANGGILAN ALLAH KEPADA ABRAHAM DALAM KEJADIAN 12:1-4
}

\author{
Kasiatin Widianto, M.Th. \\ Sekolah Tinggi Teologi Injili Indonesia Surabaya \\ E-mail:kasiatinwidianto@sttii-surabaya.ac.id
}

\begin{abstract}
God's call to Abraham is written in Genesis 12: 1-9 occurred after two heart-wrenching events of God, namely the Flood (Genesis 6 and 7) and the events of the Tower of Babel (Genesis 11), in which the wickedness of man was great and every inclination of his heart sesalu only evil-eye, therefore God destroy. Post these events God chose Abraham, it is like dew in the desert, which is soothing. His election was a saving grace in the midst of punishment that should be passed to humans.

Call of God revealed to Abraham as a person, but the impact covering all the face of the earth, where it appears in it how the nature of God's call to him, the Private nature, Separation nature, and Agreement nature.
\end{abstract}

Keywords: Abraham, Genesis, Call of God

\section{PENDAHULUAN}

Panggilan Allah kepada Abraham terjadi setelah peristiwa menara Babel yang membuat manusia diserakkan ke seluruh bumi (Kej.11). Bagai embun di padang gurun, panggilan Allah kepada Abraham merupakan anugerah keselamatan di tengah hukuman. Abraham yang menerima panggilan penting ini harus 'menanggapinya secara positif. Pangilan Allah yang dinyatakan kepada Abram (yang kemudian dinamakan Abraham - Kej. 17:5) sebagai seorang pribadi namun dampaknya meliputi semua kaum di muka bumi ini, dimana tampak di dalamnya bagaimana sifat panggilan Allah itu terhadapnya, yakni berifat Pribadi, Perpisahan dan Perjanjian. Paparan tentang ketiga sifat panggilan Allah ini diurai lebih dalam pada bagian berikut.

\section{PRIBADI}

Panggilan Allah kepada Abraham sebagaimana tercatat dalam Kejadian 12:1-9 mengawali babak baru dalam penyataan Perjanjian Lama tentang maksud Allah untuk menebus dan menyelamatkan umat manusia. Allah bermaksud memiliki seseorang yang mengenal dan melayani-Nya dengan iman yang tulus. Dari orang ini akan tampil keluarga yang mengenal, mengajarkan, dan memelihara jalan-jalan Tuhan. Terkait dengan

panggilan Allah kepada Abraham, tidak diperlihatkan tentang bagaimana cara yang digunakan oleh Allah pada saat memanggil Abraham; dalam bagian ini tidak dijelaskan bahwa Allah nampak, dalam bentuk apapun seperti semak yang menyala seperti ketika malaikat TUHAN menampakkan diri kepada Musa (Kel. 3:2) atau nampak seperti tiang awan dan tiang api tatkala TUHAN berjalan di depan umat Israel (Kel. 13:2122). Sehingga nyata tidak nampak dalam wujud atau simbol apapun tetapi hanya suara yang berbicara kepada Abram. Sehingga ini merupakan rencana Allah kepada Abram. Mungkin sekali panggilan ini disertai dengan penampakan ${ }^{1}$ tetapi, William Dirness menegaskan bahwa Allah tidak mengidentifikasikan diri-Nya. Ia hanya berkata, "Berfirmanlah Tuhan kepada Abram". ${ }^{2}$ Kendatipun demikian yang jelas bahwa panggilan Allah terhadap Abraham itu sifatnya adalah pribadi. Maksudnya adalah bahwa panggilanNya itu ditujukan kepada Abraham secara pribadi dan bukan

\footnotetext{
${ }^{1}$ John J. Davis, Eksposisi Kitab Kejadian (Malang: Gandum Mas, 2001), 177.

${ }^{2}$ William Dirness, Tema-tema Dalam Teologi Perjanjian Lama (Malang: Gandum Mas, 2013), 23.
} 
secara kolektif. Hal mana terlihat jelas dalam Kejadian 12:1, "Berfirmanlah TUHAN kepada Abram..." Kami mencatat bahwa Tuhanlah yang mengambil inisiatif terhadap Abraham. Tuhanlah yang mencari Abraham keluar dan pada kemauan dan kehendak-Nya sendiri membuat janji pribadi untuk dia dan keturunannya. ${ }^{3}$ Dalam panggilan ini Allahlah yang berinisiatif yang terlihat di depan. ${ }^{4}$ Namun demikian, pada saat Abraham memenuhi panggilan Allah ini, yakni pergi dari negerinya dan dari sanak saudaranya dan dari rumah bapanya ke negeri yang akan Allah tunjukkan kepadanya, kepergiannya tidak berangkat sendirian, tetapi Abraham membawa Sarai, isterinya, dan Lot, anak saudaranya, dan orang-orang yang diperolehnya di Haran (Kej. 12:5). Keputusan Abraham memenuhi panggilan Allah ini sekaligus berarti keputusan untuk meninggalkan kekayaan dan kenyamanan di negeri asalnya, dan ini bukanlah sebuah keputusan yang wajar. Dari sudut pandang manusia, keuntungan untuk tetap tinggal di negeri asalnya jauh lebih banyak daripada keuntungan pergi ke suatu tempat yang belum jelas tempatnya. Kendatipun demikian pergilah Abraham seperti yang difirmankan Tuhan kepadanya (Kej. 12:4). Apakah yang mendasari keputusan Abraham? Penulis Ibrani melaporkan bahwa karena iman Abraham taat, ketika ia dipanggil untuk berangkat ke negeri yang akan diterimanya menjadi milik pusakanya (11:8). Ketika kita mencermati tindakan Abraham ini tampak tergambar bahwa ia sedang meninggalkan sesuatu yang jelasjelas terlihat, yakni keberadaan di negerinya lalu pergi ke suatu tempat yang bukan hanya samarsamar, tetapi tidak kelihatan. Ini merupakan tindakan iman. Abraham dipuji bukan hanya karena satu tindakan iman, melainkan karena sikap dan kehidupan beriman. ${ }^{5}$ Kehidupan beriman tidak terdiri atas tidandakan ketaatan dalam satu perjalanan ke tempat yang agak jauh. Kehidupan iman adalah suatu pengalaman yang terus-menerus berkenaan dengan hal yang tidak kelihatan dan yang kekal. ${ }^{6}$ Terkait dengan penetapan Allah yang memanggil dan memilih Abraham, John J. Davis ${ }^{7}$ menegaskan

\footnotetext{
${ }^{3}$ Thomas R. Yeakley, God's Promises

(Singapore: The Navigators, 1997), 89.

${ }^{4}$ Wiliam Dyrness, Tema-tema Dalam Teologi

Perjanjian Lama (Malang: Gandum Mas, 2013), 113.

${ }^{5}$ John J. Davis, Eksposisi Kitab Kejadia

(Malang: Gandum Mas, 2001), hlm. 182.

${ }^{6}$ Charles R. Erdman, The book of Genesis (New

York: Fleming H. Revell, 1950), 52.

${ }^{7}$ John J. Davis, Eksposisi Kitab Kejadian

(Malang: Gandum Mas, 2001), 178.
}

bahwa tindakan Allah memanggil dan atau memilih Abraham bukan karena sesuatu kebaikan di pihak Abraham. Sebaliknya, latar belakang Abraham adalah politeistis, dan apa pun yang dia peroleh dari tangan Allah merupakan ungkapan kasih karunia yang murni.

\section{PERPISAHAN}

Panggilan Abraham melibatkan pemisahan diri dari tanah airnya, bangsanya, dan sanak saudaranya. Hal ini jelas sebagaimana tertulis dalam Kejadian 12:1, Berfirmanlah TUHAN kepada Abram: "Pergilah dari negerimu dan dari sanak saudaramu dan dari rumah bapamu ini ke negeri yang akan Kutunjukkan kepadamu". Tiga kali disebutkan dalam ayat ini, yaitu kata "dari", yang mana ketiga-tiganya menunjuk kepada suatu tempat di mana Abraham dan sanak saudaranya serta rumah bapanya tinggal. Tindakan Abraham (ayat 4) dalam memenuhi panggilan Allah perupakan pemisahan $\operatorname{diri}^{8}$ dari segala hubungan dan belenggu darah (keturunan/asal-usul) dan tanah air (adat-istiadat dan kebudayaan). Di dalam Abraham, Allah sedang menegakkan prinsip penting bahwa umat-Nya harus memisahkan diri dari segala yang menghalangi terwujudnya maksud-maksud Allah bagi hidup mereka. Alkitab dengan jelas menceritakan bahwa sebelum berimigrasi ke Palestina, Abram (kemudian dinamakan Abraham Kej. 17:5) memiliki dua rumah. Tahun-tahun awal dalam hidupnya dijalaninya di Ur dan kemudian untuk waktu yang lama dia tinggal di Haran. ${ }^{9}$ Dia harus meninggalkan semua sahabat, tetangga dan keluarganya ketika dia meninggalkan Ur dan kini orang-orang di sekitarnya di Haran. Bagi sementara orang, fakta yang Allah perhadapkan kepada Abraham itu tentu mengejutkan, di mana ia harus pergi dari negerinya dan dari sanak saudaranya, serta dari rumah bapanya. Dengan kata lain, Abraham harus meninggalkan semua yang berarti baginya.

Di dalam setiap perpindahan tersebut, tiga ikatan berupa negeri, penduduk dan sanak keluarga diputuskan. Keberangkatan Abraham memenuhi panggilan Allah merupakan pemisahan diri dari segala hubungan dan belenggu darah

\footnotetext{
${ }^{8}$ Walter Lempp, Tafsiran Alkitab: Kitab

Kejadian 12:4-25:18 (Jakarta: BPK Gunung Mulia, 2003), 24.

${ }^{9}$ Ibid, hlm. 177 mula-mula Allah memanggil Abraham di Ur, dan Allah mengulangi panggilan itu ketika Abraham berada di Haran.
} 
(keturunan/asal-usul) dan tanah air (adat-istoadat dan kebudayaan). ${ }^{10}$

Uskup Ryle mengatakan bahwa Abraham diperintahkan untuk "

(a) meninggalkan semua kepastian masa lalu, (b) menghadapi ketidakpastian masa depan, (c) mencari dan mengikuti petunjuk dari kehendak Yehovah"11 Tuntutan itu tentunya berat sekali. ${ }^{12}$ Berbagai pencobaan berat menantinya. Panggilan ini pasti diterimanya ketika dia masih tinggal di Ur (Kis. 7:2). Panggilan tersebut dibaharui kembali beberapa tahun kemudian ketika dia sudah tinggal di Haran; sebuah kota perdagangan Mesopotamia purba, merupakan tempat tinggak nenek moyang Abraham. Tempat tersebut dikatakan sebagai pusat pemujaan bulan yang dilakukan orang dengan teguh. ${ }^{13}$ Abraham tinggal di sini sampai kematian ayahnya. Di Haran, Tuhan berbicara kepada Abraham kedua kalinya, sekali lagi menyuruhnya untuk meninggalkan negaranya, teman-teman, kerabat dan keluarga dekat, dan pergi ke tempat yang nanti hendak Allah tunjukkan kepadanya (Kej. 12:1-3).

Kini saatnya untuk memperhatikan tempat tinggal Abraham, dari mana Allah memanggilnya. Ur Kasdim adalah sebuah tempat penyembah berhala. Abaham dipanggil oleh Allah untuk keluar dari tengah-tengah penyembahan berhala dan kekafiran. ${ }^{14}$ Tuhan membuat pilihan terhadap Abraham, dan dipilih dia keluar dari antara sesamapenyembah berhala ${ }^{15}$ Itu seperti Athena pada masa Paulus. Ada dewa yang disembah di mana-mana. Abraham hidup di tengah-tengah keluarga penyembah berhala seperti dikatakan Yosua. ${ }^{16}$ Berkatalah Yosua kepada seluruh bangsa itu: "Beginilah firman TUHAN, Allah Israel: Dahulu kala di seberang sungai Efrat, di situlah diam nenek moyangmu, yakni Terah, ayah Abraham dan ayah Nahor, dan mereka beribadah

\section{${ }^{10}$ Walter Lempp, Tafsiran Alitab: Kitab}

Kejadian 12:4-25:18 (Jakarta: BPK Gunung Mulia, 2003), 24.

${ }^{11}$ Genesis dalam the Cambridge Bible, hlm. 155.

${ }^{12}$ Abraham memenuhi panggilan Tuhan, meninggalkan negerinya lalu pergi ke tempat yang tidak ia ketahuinya (Ibr. 11:8) Indah, 1992), 153.

${ }^{13}$ Herbert Haag. Kamus Alkitab (Flores: Nusa

${ }^{14}$ Joseph P. Free. Direvisi dan diperluas oleh Howad F. Vos. Arkeologi dan Sejarah Alkitab (Malang: Gandum Mas, 1997), 64

${ }^{15}$ Matthew Henry's Concise Commentary

${ }^{16}$ Yosua 24:2-3 kepada allah lain”. Tentang kota Ur Kasdim, C. Leonard Wooley $^{17}$ melaporkan temuannya ${ }^{18}$ bahwa di kota itu terdapat suatu Zigurat. Dan Ziggurat itu terbuat dari batu bata yang diletakkan di atas batu, sebuah struktur yang kuat, dengan ukuran 60 meter panjangnya, 45 meter lebarnya dan sekitar 21 meter tingginya, yang dibangun sekitar 2.300 tahun sebelum Masehi. Itu adalah bangunan yang padat tanpa kamar, tanpa celah. Ada tiga tangga besar di puncaknya, dan di puncak Zigurat ada kuil untuk dewa kafir yang mereka sembah. Dari sanalah Abraham dipanggil oleh Allah ke negeri yang akan Allah tunjukkan kepadanya. Soal kapan waktu tepatnya Abraham meninggalkan Ur, tak ada jawaban yang pasti, tetapi yang jelas bahwa pada waktu itu ia telah dengan iman meninggalkan sebuah kota yang besar dan makmur, untuk menuju ke suatu tempat yang bagi dia masih samar-samar atau sama sekali tidak diketahuinya, yang dari sisi materi benar-benar tidak menguntungkan. ${ }^{19}$

Konsep mengenai pemisahan dari yang jahat ini adalah dasar dalam hubungan Allah dengan umat-Nya. Dalam Perjanjian Lama, pemisahan merupakan suatu tuntutan Allah yang terus-menerus bagi umat-Nya (Kel 23:24; Im 11:44; Ul 7:3). Dalam Perjanjian Baru, Allah memerintahkan orang percaya untuk memisahkan diri dari sistem dunia yang bejat dan dari tindakan kompromi yang tidak kudus (Yoh 17:15-16; 2Tim 3:1-5; Yak 1:27; 4:4); dari orang-orang dalam jemaat yang berbuat dosa dan menolak untuk bertobat (Mat 18:15-17; 1Kor 5:9-11; 2Tes 3:6-15); dan dari guru, jemaat, dan kepercayaan yang palsu yang mengajarkan teologi yang salah dan menyangkal kebenaran alkitabiah

17 Joseph P Free, 65. Menjelaskan hasil penggalian Leonard Woolley terkait penyembahan dewa bulan yang bernama Nanna, yang ada di Ur, tempat dari mana Abraham dipanggil. Di mana di sana terdapat Ziggurat, sebuah menara yang kuat yang dilengkapi dengan tangga-tangga batu yang kuat menuju ke puncak, yang mana di puncak itu terdapat sebuah kuil dewa. Sementara di kaki Ziggurat berdiri sebuah kuil untuk Nanna, yang tampaknya dihuni bersamasama dengan istrinya, dewi bulan Ningal. Berdekatan dengan kuil ini terdapat sebuah dapur untuk persiapan kurban persembahan yang akan dimakan oleh para dewa, iman dan penyembah.

18 John J. Davis, Eksposisi Kitab Kejadian (Malang: Gandum Mas, 2001), 176. Di mana Sir Leonard Woolley melakukan penggaliannya dari tahun 1922 sampai tahun 1934.

${ }^{19}$ Howard F. Vos. Kitab Kejadian dan Aekeologi (Yogyakarta: Yayasan ANDI, 1993), 68. 
(Mat 7:15; Rom 16:17; Tit 3:9-11;2Pet 2:1722;1Yoh 4:1; 2Yoh 1:10-11; Yud 1:12-13).

Setelah memutuskan segala ikatan dengan tanah asalnya. Abraham berangkat menuju sebuah negeri yang tidak dikenalnya. Abraham berangkat bersama dengan isterinya dan Lot, anak saudaranya dan segala harta benda yang didapat mereka dan orangorang yang diperolehnya di Haran (Kej. 12:4-5). Memang ini bukan keputusan yang mudah, Abraham meninggalkan negerinya, sanak saudaranya dan rumah bapanya lalu pergi ke tempat yang belum jelas baginya. Walaupun demikian, karena iman Abraham pentaati panggilan Allah (Ibr. 11:8). Imannya tidak buta karena ia mengetahui kuasa Allah yang telah memanggilnya dan memiliki janji-Nya akan menunjukkan kepadanya suatu negeri yang baru. Memang, ia akan meninggalkan suaru negeri dengan kota-kota besar yang kaya akan materi, tetapi Tuhan menjanjikan suatu warisan baru yang akan meliputi suatu negeri yang lain (Kej. 12:1; bdg. Kej. 13:15, 17).

\section{PERJANJIAN}

Panggilan Allah kepada Abraham tidak hanya dinyatakan dalam bentuk perintah supaya Abraham meninggalkan negerinnya, sanak saudaranya dan rumah bapanya menuju tempat yang akan Allah tunjukkan kepadanya (Kej. 12:1), namun Allah mengikat Abraham dengan perjanjian-Nya. Perjanjian-Nya kepada Abraham begitu jelas tertulis dalam Kejadian 12:2-3, sebagai berikut:

"Aku akan membuat engkau menjadi bangsa yang besar, dan memberkati engkau serta membuat namamu masyhur; dan engkau akan menjadi berkat. Aku akan memberkati orang-orang yang memberkati engkau, dan mengutuk orang-orang yang mengutuk engkau, dan olehmu semua kaum di muka bumi akan mendapat berkat."

Secara literal, dalam janji Allah ini tertulis ada tujuh hal yang terkandung di dalamnya, yakni (1) Allah akan membuat Abraham menjadi bangsa yang besar (2) Allah berjanji akan memberkati Abraham (3) Allah akan membuat namanya masyhur (4) Abraham akan menjadi berkat (5) Allah akan memberkati orang-orang yang memberkati Abraham (6) Allah akan mengutuk orang-orang yang mengutuk Abraham dan (7) melalui Abraham, semua kaum di muka bumi akan mendapat berkat. Tentang hal ini, John F. Walvoord, Roy B. Zuck ${ }^{20}$ menyatakan bahwa panggilan Abram memiliki tujuan, yakni ketaatannya akan membawa berkat yang besar. Jika Abram akan keluar Ur, Tuhan akan melakukan tiga hal untuk dia, sehingga ia kemudian bisa menjadi berkat di tanah yang akan ditunjukkan kepadanya. Tiga janji yang berdasarkan panggilan Allah bagi Abram untuk meninggalkan negerinya: (a) suatu bangsa yang besar, (b) berkat bagi Abram, dan (c) namanya mashur (ayat.2).

Ditambahkan, dan ia harus menjadi berkat sehingga Allah akan melakukan tiga hal lagi yang seimbang dengannya, yakni Allah akan: memberkati orang-orang yang memberkatinya, (b) mengutuk siapa saja yang akan memperlakukan dia ringan, dan (c) memberkati keluarga di bumi melalui dia (ayat 3). Janji Allah, sebagaimana yang Dia katakan kepada Abraham (Ke.12:2-3) tidak lain adalah merupakan suatu kompensasi ${ }^{21}$ terhadap apa yang harus Abraham lakukan terhadap panggilanNya, yaitu harus meninggalkan negerinya, sanak saudaranya dan rumah bapanya.

Penjanjian Allah ini merupakan satu perjanjian, tetapi memiliki tiga bagian atau unsur ${ }^{22}$, yang akan dilaksanakan oleh Allah, yang tidak bisa dibatalkan oleh apapun yang dibuat oleh Abraham dan keturunannya ${ }^{23}$, di mana ketiga unsur itu meliputi tanah, benih dan berkat, dan ketiga unsur perjanjian ini akan diberikan menyusul setelah Abrahan meninggalkan negerinya, kerabatnya dan rumah bapanya, dan ini merupakan sebuah pengorbanan. ${ }^{24}$ Ketiga unsur perjanjian itu jelas terlihat dalam Kejadian 12:1-3. Ayat 1 merupakan janji yang terkait dengan tanah; ayat 2 merupakan janji yang berhubungan dengan benih atau keturunan; kemudian janji yang berkaitan dengan berkat tertulis dalam ayat 3 .

Masih dalam kaitannya dangan janji Allah kepada Abraham, Charles C. Ryrie menyatakan ada tiga aspek yang terdapat di dalamnya, masing-

${ }^{20}$ John F. Walvoord, Roy B. Zuck, The Bible

Knowledge Commentary (Canada: Victor Books, 1985), 47.

${ }^{21}$ Pulpit Commentary

22 Carl A. Reed. Diktat Kuliah Program S-3. Teology of the Pentateuch (Yogyakarta: Sekolah Tinggi Teologi Injili Indonesia, 2014), 87.

${ }^{23}$ Ibid, hlm. 88.

${ }^{24}$ Edward E. Hindson, Wooddrow Michael

Kroll, The K.J.V Parallel Bible Commentary (Nashville,

Tennessee: Thomas Nelson, 1994), 44. 
masing adalah janji secara pribadi kepada Abraham, janji secara universal dan janji secara nasional. ${ }^{25}$ Ditambahkan, janji Allah secara pribadi, "Aku akan membuat engkau menjadi bangsa yang besar, dan memberkati engkau serta membuat namamu masyhur; dan engkau akan menjadi berkat" (Kej. 21:2). Ketika janji ini disampaikan, Abraham belum punya anak; tentunya jannji ini menunjuk pada bangsa Yahudi, keturunan Abraham melalui Ishak dan Yakub. Adapun tentang janji Allah yang akan memberiakti Abraham, penggenapannya telah dinyatakan dalam pasal-pasal berikutnya, yakni berupa tanah (Kej. 13:14-17), para budak (Kej. 15:7), kekayaan (Kej. 13:2; 24:34-35), dan Tuhan memberinya berkat rohani $(13: 12 ; 21: 22)$. Janji bahwa Abram akan menjadi bangsa yang besar diulang dalam pasal 18:18. Lalu diulangi lagi terkait dengan Ismail (17:20; 21:18) dan Yakub (46: 3) juga berjanji bahwa mereka masing-masing akan menjadi bangsa yang besar. Selanjutnya, janji secara universal, "Aku akan memberkati orang-orang yang memberkati engkau, dan mengutuk orang-orang yang mengutuk engkau, dan olehmu semua kaum di muka bumi akan mendapat berkat" (Kej 12:3). Kedekatan hubungan Abraham dengan Tuhan begitu erat, sehingga memberkati dia atau mengutuk dia mempengaruhi berkat dan kutuk Allah. (Kej. 20:12; 21:22-34; 23). "Aku akan memberkati orang-orang yang memberkati engkau", di dalam Abraham segala macam manusia akan mengenali dan mengakui berkat dari Allah, Tuhan semesta alam. Dan banyak orang akan menerima baik dan menyambut Abraham sebagai pembawa berkat. Mereka semuanya akan menerima bagian dan warisan berkat yang sama dengan yang dipunyai Abraham. Berkat yang dari Allah tidaklah terbatas, adalah universal, ditunjukan kepada seluruh manusia, kepada seisi dunia, tetapi dengan perantaraan Abraham dan bukan tanpa keputusan yang harus diambil di waktu berhadapan dengan Abraham. Selanjutnya, dikatakan "dan mengutuk orang-orang yang mengutuk engkau", sebagaimana janji Allah bahwa Ia akan memberkati orang-orang yang memberikati Abraham, sebaliknya Ia akan menghukum orang-orang yang mengutuk Abraham, hamba-Nya. Hal ini tidak lain merupakan suatu pembelaan Allah terhadap Abraham, yang dipilih-Nya. Bagian akhir dari janji-janji-Nya, Allah menegaskan kepada Abraham, "olehmu semua kaum di muka bumi akan mendapat berkat", itulah kemauan Allah. Alangkah besar pemanggilan

${ }^{25}$ Charles C. Ryrie, Teologi Dasar 2

(Yogyakarta: Yayasan ANDI, 1992), 267-269
Abraham. Berkat itu diberikan dengan perantaraan Abraham dan keturunannya (bnd. Kej 22:18; 26:4; 28:14), dan berkat itu adalah berkat Allah.

Jawaban Abraham terhadap panggilan dan janji-janji Allah dia wujudkan bukan dalam bentuk perkataan tetapi dalam tindakan, "Lalu pergilah Abram seperti yang difirmankan TUHAN kepadanya," (Kej. 12:4). Jawaban atas firman Allah itu tidak terdiri dari kata-kata dan pembicaraan, melainkan dari tindakan, dari kehidupan. ${ }^{26}$ Dalam usia tujuh puluh lima tahun Abraham meninggalkan Ur Kasdim di Mesopotamia (ayat 4). Keputusan yang dibuat oleh Abraham ini merupakan sebuah keputusan yang sangat berani; bahkan tidak dapat dianggap sebagai sesuatu yang wajar. ${ }^{27}$ Dari sudut pandang manusia, keuntungan untuk tinggal di negerinya jauh lebih banyak daripada keuntungan ketika ia meninggalkan negerinya. Belum lagi kepergiannya itu menuju suatu tempat yang masih samar-samar baginya ("ke negeri yang akan Kutunjukkan kepadamu" - ayat 1), dapatkah hal ini dikatakan sebagai suatu tindakan yang sembrono? Terhadap tindakan Abraham ini Walter Lempp menyatakan bahwa tindakannya itu merupakan langkah yang luarbiasa yang disebabkan oleh desakan suara Allah; perjalanannya adalah perjalanan dinas. $^{28}$

Seiring perjalanan waktu, yakni hari-hari setelah kepergiannya meninggalkan negerinya dalam rangka mewujudkan kepatuhannya kepada panggilan Allah, Allah pun memenuhi janji-janjiNya yang telah diucapkan kepada Abraham. Janji yang terkait dengan "berkat dan namanya mashur", Allah telah memenuhinya, di mana Abraham menjadi kaya, baik ternak, perak maupun emasnya (Kej. 13:2) dan namanya mulai mashur (Kej. 14) bahkan, ia diberkati Allah dalam segala hal (Ke. 24:1). Selanjutnya, janji Allah terkait dengan "kutuk" (Kej. 12:3) yaitu Allah akan mengutuk orang-orang yang mengutuk Abraham, sudah Allah buktikan kepada Firaun pada saat mengambil Sarai sebagai istrinya (Kej. 12:17-20).

Demikian juga halnya tentang janji Allah tentang "keturunan" Abraham. Ini sebuah penantian

Kejadian, hlm. 25 .

${ }^{26}$ Walter Lempp, Tafsiran Alkitab: Kitab

${ }^{27}$ John J. Davis, hlm. 31.

Kejadian, hlm.25. 
yang panjang. Janji tentang hal ini telah disampaikan kepada Abraham dalam pasal 12; beberapa kali Allah berusaha meyakinkan Abraham akan realitas pemenuhan janji-Nya. Dalam Kejadian 16, Abraham kini berusia 85 tahun (ayat 3) dan telah berjalan dengan iman dengan janji-janji Allah selama sepuluh tahun. Dia telah meninggalkan semua dan Tuhan telah membawa dia ke lahan baru, tetapi ia masih tidak memiliki ahli waris sesuai dengan janji Allah. Selama sepuluh tahun terakhir, Tuhan telah berbicara dengan dia empat kali, mendorong dia, dan menegaskan kembali janji-janji-Nya.

Abraham tampaknya telah kehabisan ketekunan dan mengendap untuk kompromi, percaya pada kemampuannya sendiri untuk membedakan jawaban Allah. Dia memiliki seorang putra, Ismail, melalui hambanya perempuan, Hagar, berpikir bahwa kehendak-Nya pasti menjadi jawaban Tuhan.

Dalam Kejadian 17, Abraham kini berusia 99 tahun dan masih tinggal di Hebron, Allah lagi berbicara kepadanya untuk keenam kalinya dan meyakinkannya bahwa janji akan terpenuhi. Nama Abraham berubah dari Abram ke Abraham, ('bapa banyak bangsa,) dan Sarah dari Sarai ke Sara. Tuhan menjelaskan lebih lanjut janji tanah dan bahwa dalam waktu satu tahun, Sara akan melahirkan seorang putra yang akan diberi nama Ishak (ayat 21). Abraham merespon dengan jatuh tertelungkup dalam ibadah dua kali (ayat 3, 17), namun ia masih bertanya-tanya bagaimana Tuhan akan memenuhi janji melihat dia dan Sara sekarang juga maju dalam usia (ayat 17). Tetapi, ia mematuhi Tuhan dengan menyunat dirinya dan setiap laki-laki di rumahnya seperti kondisi janji (ayat 29-27).

Dalam Kejadian 18, Abraham dikunjungi untuk ketujuh kalinya oleh Tuhan dan dua malaikat, yang sedang dalam perjalanan mereka untuk menghancurkan Sodom dan Gomora (ayat 1-33). Tuhan berjanji untuk kembali dalam waktu satu tahun dan dalam rentang waktu, seorang anak akan lahir dari Sara, isterinya (ayat 10). Sara meragukan janji karena usia yang ekstrim, tetapi Allah mengulanginya, lembut menegur dia, bersaksi untuk kemampuan-Nya untuk melakukan sesuatu Dia berjanji dan mengatakan bahwa pasti dia akan memiliki seorang putra dalam tahun depan (ayat 1314). Pada akhirnya Allah memenuhi janji-Nya, Sara mempunyai anak seperti yang dijanjikan-Nya" (Kej. 21: 1). Ishak, anak yang dijanjikan itu lahir setelah
25 tahun ditunggu, ketika Abraham berusia 100 tahun (21: 5). Antara waktu pemberian janji awal di Haran kelahiran hingga Ishak, 25 tahun telah berlalu dan Allah telah berbicara kepada Abraham lima kali, meyakinkannya bahwa semua akan terjadi seperti yang dijanjikan. Selanjutnya, dalam kurun waktu ratusan tahun pemenuhan janji Allah, "Aku akan membuat engkau menjadi bangsa yang besar" (Kej. 12:2) telah menjadi kenyataan; hal ini tertulis dalam kitab Keluaran $(12: 37,41)$ pada saat bangsa Israel dari Mesir, dilaporkan kira-kira enam ratus ribu orang laki-laki, belum termasuk anak-anak, bahkan ada yang menyebut kurang lebih dua juta orang. ${ }^{29}$ Selanjutnya, dalam janji-jani Allah kepada Abraham juga terkandung kepemilikan suatu tanah. Pada waktu Abraham tida di Kanaan, Allah memberitahu bahwa negeri ini akan diberikan kepada keturunannya (Kej.12:7). Seperti halnya janjiNya kepada Abraham berkaitan dengan keturunan yang diulang-ulang sampai beberapa kali sebelum akhirnya digenapi; demikian pula janjiNya terkait dengan kepemilikan tanah diulang-ulang, bukan saja disampaikan kepada Abraham tetapi disampaikan ulang kepada keturuannya sebelum akhirnya baru akan digenapi 400 kemudian, ${ }^{30}$ di mana janji itu disampaikan kepada Ishak, anaknya (Kej. 26:3) dan kepada Yakub (Kej. 28:13; 35:12). Bahkan sesaat sebelum kematiannya, Yakub pun mengingatkan Yusuf, anaknya akan janji Allah kepadanya di Betel, yang meyakinkan Yakub bahwa Kanaan akan menjadi miliknya sampai selamalamanya (Kej. 48:3-4).

29 Thomas R. Yeakley, God's Promises Singapore: The Navigators, 1997), 99.

${ }^{30}$ Carl A. Reed. Diktat Kuliah Program S-3. Teology of the Pentateuch (Yogyakarta: Sekolah Tinggi Teologi Injili Indonesia, 2014), 93. 


\section{KEPUSTAKAAN}

Davis, John J. Eksposisi Kitab Kejadian. Malang: Gandum Mas, 2001.

Erdman, Charles R. The book of Genesis. New York: Fleming H. Revell, 1950.

Free, Joseph P. Direvisi dan diperluas oleh Howad F. Vos. Arkeologi dan Sejarah Alkitab. Malang: Gandum Mas, 1997.

Haag, Herbert. Kamus Alkitab. Flores: Nusa Indah, 1992.

Hindson Edward E., Wooddrow Michael Kroll, The K.J.V Parallel Bible Commentary. Nashville, Tennessee: Thomas Nelson, 1994), 44.

Lempp, Walter. Tafsiran Alitab: Kitab Kejadian 12:4-25:18. Jakarta: BPK Gunung Mulia, 2003.

Matthew Henry's Concise Commentary

Reed, Carl A. Diktat Kuliah Program S-3. Teology of the Pentateuch. Yogyakarta: Sekolah Tinggi Teologi Injili Indonesia, 2014.

Ryrie, Charles C. Teologi Dasar 2. Yogyakarta:

Yayasan ANDI, 1992.

Vos, Howard F. Kitab Kejadian dan Aekeologi.

Yogyakarta: Yayasan ANDI, 1993.

Walvoord, John F. Roy B. Zuck. The Bible Knowledge Commentary. Canada: Victor Books, 1985.

Wolf, Herbert. Pengenalan Pentateukh. Malang: Gandum Mas, 1998.

Yeakley, Thomas R. God's Promises. Singapore: The Navigators, 1997. 